Hanrath, Scott and Erik Radio. "User Search Terms and Controlled Subject Vocabularies in an Institutional Repository." Library Hi Tech 35, no. 3 (July 2017): 360-367.

Harrington, Caitlin and Rachel Scott. "Working around the ERM: Automating Accurate Electronic Serials Holdings Data in Bibliographic Records." Serials Librarian 73, no. 1 (September 2017): 11-17.

Kalwara, James, Melody Dale, and Marty Coleman. "GMD or No GMD: RDA Implementation for a Consortial Catalog." Library Resources E Technical Services 61, no. 3 (July 2017): 162-170.

Kohl, Laura, Claire-Lise Bénaud, and Sever Bordeianu. "Finding Shelf Space in an Academic Library: A Multifaceted Approach." Technical Services Quarterly 34, no. 3 (July 2017): 268-282.

Lin, Xia, et al. "Mapping Metadata to DDC Classification Structures for Searching and Browsing." International Journal on Digital Libraries 18, no. 1 (March 2017): 25-39.

Mccallum, Carolyn, et al. "Can RDA Content, Media, and Carrier Coding Improve Discovery Facet Mapping?" Library Resources EF Technical Services 61, no. 2 (April 2017): 93-101.

Ou, Carol, Katherine L. Rankin, and Cyndi Shein. "Repurposing ArchivesSpace Metadata for Original MARC Cataloging." Journal of Library Metadata 17, no. 1 (January 2017): 19-36.

Taniguchi, Shoichi. "Examining BIBFRAME 2.0 from the Viewpoint of RDA Metadata Schema." Cataloging E Classification Quarterly 55, no. 6 (August 2017): 387-412.

Van Hyning, Victoria, et al. “Transforming Libraries and Archives through Crowdsourcing.” D-lib Magazine 23, no. 5/6 (May/June 2017): 1, doi: https://doi.org/10.1045/may2017-vanhyning

Wakeling, Simon, et al. "Users and Uses of a Global Union Catalog: A Mixed-Methods Study of WorldCat.org." Journal of The Association for Information Science EO Technology 68, no. 9 (September 2017): 2166-2181.

Zapounidou, Sofia, Michalis Sfakakis, and Christos Papatheodorou. "Representing and Integrating Bibliographic Information into the Semantic Web: A Comparison of Four Conceptual Models." Journal of Information Science 43, no. 4 (August 2017): 525-553.

Submitted by

Anna Appleman, Cataloger

John Bulow Campbell Library, Columbia Theological Seminary

TESTIMONY

\title{
THE JOURNEY TO CATALOGING
}

The following stories are the journeys of our colleagues to becoming catalogers. We each have a unique story of that process and I think it's insightful to know these stories so that we can facilitate the path of others to finding cataloging as their career. Through each story, I think you will see how important a timely word from a colleague can be to guiding someone into the field of cataloging.

\section{Synchronicity}

I never consciously pursued cataloging as a career. I had a library degree that sat unused and almost forgotten for 13 years. My undergraduate degree is in English (and as a librarian I'm sure I am not alone in that). After graduating I found it difficult to find a job that would use my skills. While working as a clerk at a dry cleaning store, in the process of following any avenue to seek a better opportunity, I took a civil service exam and promptly forgot about it. A year or so later I was contacted and told that a job was open for me at a public middle school as a library clerk. There was no interview, if I wanted the job, it was mine. I worked in that position for four or five years, checking in periodicals, filing cards, and helping students with these newfangled devices called computers that could do word processing. It was the school librarian there who encouraged me to 
go to library school. At the time I lived in Rochester, New York, and the closest library school was in Buffalo. Well before the days of online classes, this school offered classes in Rochester at the local community college where I could complete half of the credits for the program. I finished my degree in December of 1989, six months after the birth of my first child. This is why the diploma sat on the shelf for 13 years as I was able to be a stay-at-home mom.

Fast forward to 2002, my youngest child is in elementary school and my husband and I had agreed that I would start to look for a job. There was also an added urgency to the process because my husband had been laid off. I saw an ad in the newspaper for a librarian position and applied for it. It was for a job at a Seminary, a cataloging job. Was I thrilled? I was thrilled to be offered a library job for sure. Cataloging, I feel, I just fell into. However, I was fortunate to have two very-well qualified colleagues who mentored me. My supervisor had been part of the National Library of Canada and had served on the committee for the formation of the guidelines in music cataloging for AACR2. My coworker had served for many years at the NC State libraries, retired and then a year later realized she still wanted to work. Their combined expertise was invaluable to me. Now, 15 years later, I am still at the same school, my cataloging colleagues have retired, and I am Head of Technical Services. What a long strange trip it's been.

Submitted by

Donna Wells, Head of Technical Services

The Library, Southeastern Baptist Theological Seminary

\section{Conversion}

Some catalogers are born; some are not. I was not. I was converted.

In the beginning. My first job is a library was to shelve newspapers and keep the currently received journals in order. As a $\mathrm{PhD}$ candidate at the University of Chicago, my experience broadened from shelving to a master of all trades, (all except cataloging). I circulated books, processed books, filed cards, and read shelves.

Then the call came. The money ran out. Now it was time to get a real job while trying to complete my dissertation. I became a research editor in the field of religion for the 15th edition of the Encyclopaedia Britannica fact-checking the articles. For people, two sources were needed to confirm dates; three were needed to change them. The editors created data verification records (DVRs) for people in order to facilitate fact-checking.

After my stint at the Encyclopaedia, I still had to find a job. I had always worked in libraries, so I said to myself, "Let's look around." I was hired as a circulation assistant at the Center for Research Libraries and filled requests received by either phone, mail, or teletype. A new position opened up and I was hired as the supervisor of the Foreign Newspaper Project. The Project collected print copies of newspapers worldwide.

One day a colleague said, "If you want to go further, you have to get a library degree."

So I took night courses at Rosary College (now Dominican University). The experiences I had gained from working in libraries informed the classes I took. In the cataloging courses, students who had worked in cataloging departments would add details to the discussions which were beyond me. Occasionally, during these discussions, I would hear, "Even Gene..." Feeling at the bottom of the barrel, I had to make sure I didn't stay there.

After earning the library degree, I became head of the order section for non-serial publications at the University of Illinois, Chicago. However, I was still looking for a "professional" position. I wanted to be a reference librarian or a rare books/ materials librarian. Then ATLA advertised for a cataloging position for their monographic preservation project. I applied even though I had no cataloging experience. My eventual boss, Bob Markham, said, "I don't care about what you don't know about AACR2. I care about what you know about religion.” So there I was. Lone cataloger. No experience. What to do? I spent a lot of time reading the LC rule interpretations as they appeared in the Library of Congress' Cataloging Service 
Bulletin. My cataloging was at first checked by a committee and then by other catalogers who were eventually hired. Greatest cataloging practicum, ever. Thank you ATLA!

From there, I moved on to the cataloging position at Bethany Theological Seminary and then to the Claremont School of Theology. I eventually joined the ATLA NACO funnel project and began creating authority records for people, titles, corporate bodies, and geographical names (not unlike the DVRs at the Encyclopaedia Britannica). Through the use of the Library of Congress Classification System, I became entranced by the beautiful simplicity of it. Yes, there are holes in some of the classes, but the cuttering is so simple. Elegant simplicity. I became more and more appreciative of what the classification system was trying to do: keep like materials in one place. I recalled a comment made many years ago by a professor at Rosary College about the purpose of the library: to preserve, curate human literature for all. So through applying, at first, the "rules," I have come see cataloging and classification as universal for all of human lore and not just for one's own local library and to see cataloging and classification as the Foundation, the Fundamental of all librarianship.

Not born. No. Converted. Yes. Complete(ly).

\author{
Submitted by \\ Gene Fieg, Retired
}

\title{
My Journey
}

I grew up loving libraries, attending Storytime with Miss Terry when I was in preschool and later taking weekly library trips that ended with me toting home stacks of books ranging from Bill Peet and Mrs. Piggle Wiggle to Sherlock Holmes and Encyclopedia Brown. The summer when I was 12, I volunteered as a children's picture book shelver, while another summer I helped move library books to a new building. But as much as I loved libraries, I didn't know them as well as I thought.

When I applied for a student worker position at my college library, I expected to get a job shelving books or sitting at a circulation desk, because that's what one did in libraries. When the library called me to interview for a technical services position, I had no idea what technical services even was, but it was in a library, so I was willing to try it. In spite of my ignorance, the library hired me, and I learned to shelf read the serials, process newly cataloged books for shelving, type information on microfiche envelopes, and create brief MARC records for gift books. The jargon was a challenge at first. Boxes for serials made me think of cereal boxes, "brief bibs" (for short bibliographic records) brought baby bibs to mind, and I didn't understand the difference between a PO (purchase order) and an invoice. The acronyms were even more confusing.

After three years working there, I graduated as a music major without a plan for what I might do next. A few weeks later I received an e-mail from the technical services librarian saying that my former cataloging supervisor had left the position and would I be interested in applying for the position? When the library hired me, the technical services librarian taught me more about MARC, AACR2, subject cataloging, and classification, and I loved it. Since I grew up sorting toys by color and entering genealogical data into a database for fun, classifying library materials and entering metadata into a database seemed a natural step forward.

I still loved the work after a few years in that position, so I began an MLIS degree, which taught me that as much as I loved libraries, I still didn't know them as well as I thought. Information behavior theory almost took me out the first semester. I knew the practical side of the library, but this theory stuff was new and confusing. Even my information organization classes were a challenge. Having cataloged for over four years, I thought the classes would mostly review what I already knew. But, you guessed it, they taught me more theory. They tried to drill "subject-predicate-object" into my head, and I had no idea what that meant, looking up the terms in dictionaries and finding the grammatical definitions even more confusing. I couldn't understand what this had to do with cataloging. It wasn't until later that I realized this was the foundation of RDF triples, a key component to my current research interest: Linked Data. My professors knew I needed the theory more than I did. 
Before I graduated, our technical services librarian took a new position, and the library director asked if I would take her place, even though I wouldn't qualify as library faculty until after graduation. After the transition, I managed both the cataloging and acquisitions areas of the library and was responsible for the original cataloging. This allowed me to lead a project to reclassify our materials from Dewey Decimal to Library of Congress classification and teach myself music cataloging with a $\$ 10,000$ music score donation. Those opportunities in turn gave me the cataloging and management experience for my current position, in which I have learned how to use MarcEdit, shelf-ready cataloging management, and rudimentary rare book cataloging. Through cataloging, I've learned that as much as I love libraries, I will never know as much about them as I think I do, which makes me love them more.

\author{
Submitted by \\ Christa Strickler, Resource Description Librarian \\ Buswell Library, Wheaton College
}

